\title{
EDITORIAL
}

\section{"LIMITAÇŐES" DA TEORIA ECOLÓGICA DA SAÚDE E DOENÇA}

Encontra-se em andamento, e logrando bastante aceitação por parte de determinada corrente de pensamento, a tentativa um tanto maniqueísta, de combater a teoria que parte do conceito ecológico de saúde. Como se sabe, este a concebe como sendo o estado de perfeita e contínua adaptação do homem ao seu ambiente (Wylie, 1970). As "baterias" que se assentam contra essa concepção partem da premissa de que "o ecológico está limitado ao componente físico-biológico do ambiente no qual vive o homem" (Barbosa, 1985). Com isso, pretende-se acusar os estudos epidemiológicos até agora praticados de, em sua maioria, terem cometido a imperdoável falta de ignorarem, em boa medida, os determinantes sociais da doença. É possível que esse fato tenha ocorrido. No entanto, nem por isso é de se admitir que a teoria ecológica seja encarada como intrinsecamente limitada.

O sentido que atribui significado ecológico ao processo de saúde e doença, embora cientificamente bem alicerçado, de maneira involuntária tem contribuido para a crença errônea de que o estado de sanidade individual e o coletivo constituem objetos de estudo a serem tratados separadamente. Em outras palavras, a saúde da pessoa poderia ser encarada independentemente do estado de saúde da população. Para esse tipo de interpretaçăo teria contribuído a ênfase dada aos fatores biológicos na gênese da doença. Na atualidade, tem crescido a tendência de encarar este fenômeno, não apenas incluindo a participação individual, mas também, e necessariamente, a social. Entre outras conceituaçðes, focaliza-se o "papel de doente" que o indivíduo assume na sociedade, ou seja, a correspondente disfunção social afetando o seu relacionamento com os demais individuos normais (Susser, 1973). Assim pois, o processo saúde e doença é visto como sendo de natureza precipuamente social. O conceito de saúde deve ultrapassar os estreitos limites da ausência da doença pois, caso contrário, não se poderá pretender a melhoria da qualidade da vida, mas sim tão somente a mera sobrevivência a qualquer preço (Viniegra, 1985). Com tal orientação, ao invés de na "História Natural da Doença", os estudos tendem a se concentrar em uma suposta "História Social da Doença", cujo objeto principal "deverá ser a distribuição desigual da doença entre os diferentes grupos da sociedade" (Almeida Filho, 1989).

Face a tal situação, cabem comentários. Antes de tudo, é de se admitir que o que disso resulta é aspecto apenas aparentemente discordante. $\mathrm{E}$ até porque, os estudos sobre a saúde populacional humana devem obrigatoriamente levar em conta aspectos e fatores tanto biológicos como sociais. Não há motivo plausível para confinar aos primeiros a concepção ecologica de saúde, ou de qualquer relacionamento antrópico. A ecologia humana nunca poderá ignorar a existência da sociedade, como se o organismo do homem fosse simples participante de população destituída de estruturas sociais altamente complexas. E, como está longe de ser apenas geneticamente determinada, à semelhança das de formiga e de abelhas, a sociedade humana, em seus aspectos estruturais e de desenvolvimento cultural, é fator determinante do seu próprio estado de saúde, tanto individual como coletiva.

Isso, porém, deve ser cientificamente encarado mediante o estudo ecológico da população humana em sua própria sociedade, e dos conseqüentes determinantes que daí se originam para o seu estado de saúde. E lícito que o estudo ecológico implique, também e necessariamente, a focalização do comportamento intra-específico na população humana, e de onde se originam os fatores da natureza sócio-econômica e cultural. Assim sendo, a palavra "ambiente" deve ser entendida em seu significado por inteiro, que inclui obrigatoriamente o meio social. Com esse entendimento, o estudo ecológico da dinâmica da saúde e da doença abrange toda a problemática populacional nesse campo. Poder-seia falar em teoria sociológica desse processo. Isso, contudo, levará a limitação do conhecimento para outro extremo, porém em tudo análoga à que supostamente se tem atribuído à teoria ecológica.

\section{REFERENCIAS BIBLIOGRÁFICAS}

ALMEIDA FILHO, N. de Epidemiologia sem números. Rio de Janeiro, Ed. Campus, 1989.

BARBOSA, F. S. A epidemiologia como instrumento de transformação. Cad. Saúde públ., Rio de Janeiro, 1: 137-9, 1985.

SUSSER, M. Causal thinking in the health sciences. New York, Oxford University Press, 1973.

VNIEGRA, V. L. Hacia un concepto de salud coletiva. Salud publ. Mexico, 27: 410-8, 1985.

WYLIE, C. M. The definition and measurement of health and disease. Publ. Hlth, Rep., 85:100-4, 1970.

Oswaldo Paulo Forattini Editor 